\title{
ICP-MS Analysis of Mercury in Fish: Exploration of Method Validation, Matrix Effect, and Kinetic Energy Discrimination
}

Wonhyeuk Jung* $\dagger$, Christopher S. Dunham* ${ }^{\star}$, Katie A. Perrotta $\dagger$, Yu Chen $\ddagger$, James K. Gimzewski $\dagger \#$, Joseph A. Loo†\#

$5 \dagger$ †epartment of Chemistry and Biochemistry, University of California, Los Angeles, California 90095, United States

$\ddagger$ Molecular Instrumentation Center, University of California, Los Angeles, California 90095, United States

\#Department of Biological Chemistry, David Geffen School of Medicine, University of California, Los Angeles, California 90095, United States

\#\#California NanoSystems Institute, University of California, Los Angeles, California, 90095, United States

*These authors contributed equally to this work.

\section{ABSTRACT}

Inductively coupled plasma-mass spectrometry (ICP-MS) is a powerful analytical technique that can quantify elements of interest at parts-per-trillion concentrations. In this laboratory class, students performed ICP-MS analysis to quantify mercury concentration of standard reference material (SRM) 1947 (Lake Michigan fish tissue) and canned tuna from a local supermarket. These two samples were digested in two different matrices $\left(\mathrm{HNO}_{3} / \mathrm{H}_{2} \mathrm{O}_{2}\right.$ or $\left.\mathrm{HNO}_{3} / \mathrm{HCl} / \mathrm{H}_{2} \mathrm{O}_{2}\right)$ and then analyzed using no-gas mode or helium mode with two different kinetic energy discrimination voltages (2V or $4 \mathrm{~V})$. The inclusion of $\mathrm{HCl}$ in the matrix produced more accurate results and stabilized mercury over the 8-day period after the digestion. Based on their analysis, the students were asked to draw their own conclusions about what they perceived to be the most accurate representation of the true mercury concentration of the tuna samples. This laboratory class provides students with a wide range of scientific concepts to explore such as method verification with SRM, kinetic energy discrimination, matrix effect, and trace metal stability over time. 


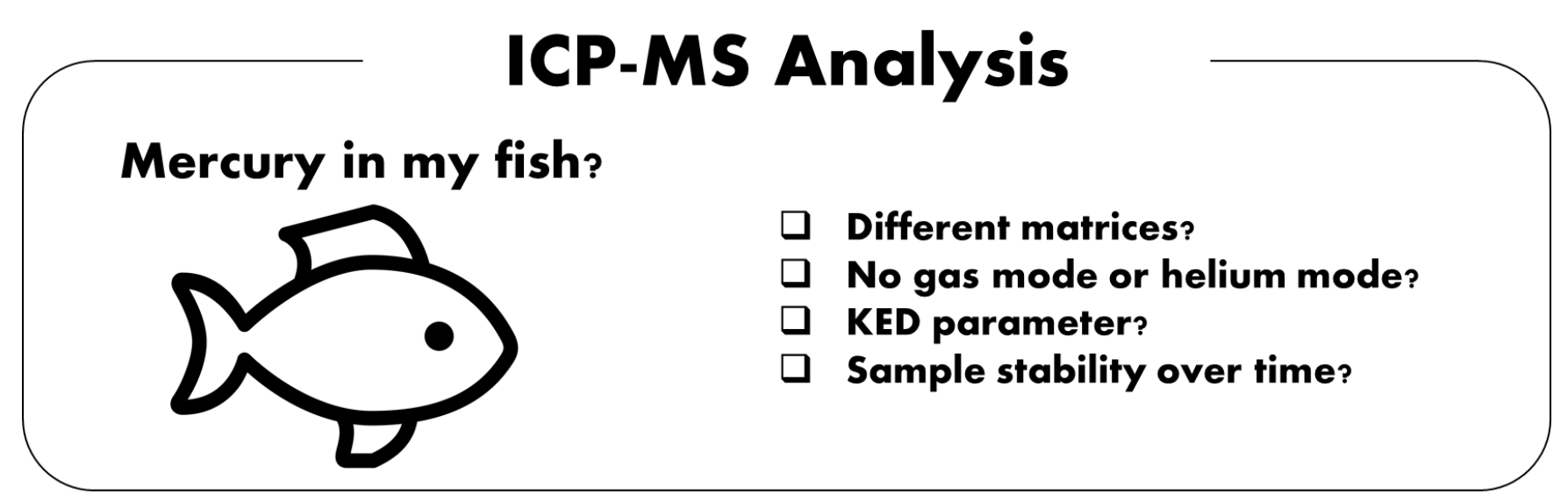


to remove products from the market. The FDA regularly updates the elemental analysis manual for food and related products and inductively coupled plasma-mass spectrometry (ICP-MS) is one of the primary methods for the quantification of mercury in fish by the FDA. ${ }^{11}$

ICP-MS is a sensitive tool for elemental quantification with diverse applications such as environmental sample analysis, water quality control, and food analysis. ${ }^{12-16}$ In the Journal of Chemical Education, the general principle of ICP-MS has been reviewed. ${ }^{17}$ Additionally, previous publications in this journal investigated analysis of trace metals in sinus wash and apple juice, explored parameter optimization through simulation, and examined the effects of polyatomic interference. ${ }^{18-22}$ Also, an undergraduate experiment analyzing mercury in fish samples using coldvapor atomic absorbance has been published ${ }^{23}$; however, to date, mercury analysis of solid foodstuffs with ICP-MS in a class setting has not been published. Thus, in this educational paper, we pursued the following learning objectives while performing mercury ICP-MS analysis on fish samples:

1. Method validation with standard reference material (SRM).

2. Matrix effect: how different acid composition affects accuracy of the analysis and sample stability over time.

3. Kinetic energy discrimination (KED) effect on accuracy of the analysis as KED voltage is varied.

In ICP-MS studies, it is common practice to use standard reference materials (SRMs) in order to validate the accuracy of the method. ${ }^{24}$ The reference material has a known concentration of the element(s) you are designing the workflow for, in a matrix similar to the unknown sample. In this experiment, SRM 1947 (Lake Michigan Fish Tissue - certified by NIST) ${ }^{25}$ was incorporated so that students could determine which combinations of parameters resulted in the most accurate results. Then, students were asked to translate this information into estimates about mercury concentrations in the canned tuna samples. The average level of mercury in canned tuna samples, as determined by the FDA, was provided so that students can make conclusions about the accuracy of their unknown analysis.

Use of $\mathrm{HNO}_{3}$ as the matrix, rather than $\mathrm{HCl}$, is generally recommended for ICP-MS analysis to avoid isobaric interference caused by Cl-based polyatomic species. ${ }^{26}$ However, Agilent reported detecting parts per trillion level of $\mathrm{Hg}$ with $\mathrm{He}$ or $\mathrm{O}_{2}$ mode with 0.5 to $1.0 \% \mathrm{HCl}$ used as the matrix. ${ }^{26-27}$ 
Also, $\mathrm{HCl}$ has been found to promote stable storage of trace amounts of $\mathrm{Hg}$, especially in combination with $\mathrm{HNO}_{3}$ and $\mathrm{H}_{2} \mathrm{O}_{2} .{ }^{28-30}$ Thus, with a correct implementation of the collision/reaction cell, the addition of $\mathrm{HCl}$ into the matrix for trace level $\mathrm{Hg}$ can be beneficial in terms of both ICP-MS analysis accuracy and long-term sample stability. To examine this aspect of the matrix effect, SRM 1947 and canned tuna from a local supermarket were digested with either $\mathrm{HNO}_{3} / \mathrm{H}_{2} \mathrm{O}_{2}$ or $\mathrm{HNO}_{3} / \mathrm{HCl} / \mathrm{H}_{2} \mathrm{O}_{2}$ and then analyzed 1 day after and 8 days after the digestion. Stability over time is an important metric in an undergraduate experiment, since funds and time restrictions may only allow for one sample digestion that must last the duration of the class.

The main instrument of this study is Agilent 8800 ICP-MS, which utilizes the collision/reaction cell between two quadrupoles to attenuate isobaric interference. ${ }^{31}$ The collision/reaction cell can be disabled (no-gas mode) or filled with either non-reactionary, e.g. He, or reactionary gases, e.g. $\mathrm{H}_{2}$ or $\mathrm{NH}_{3} \cdot 32$

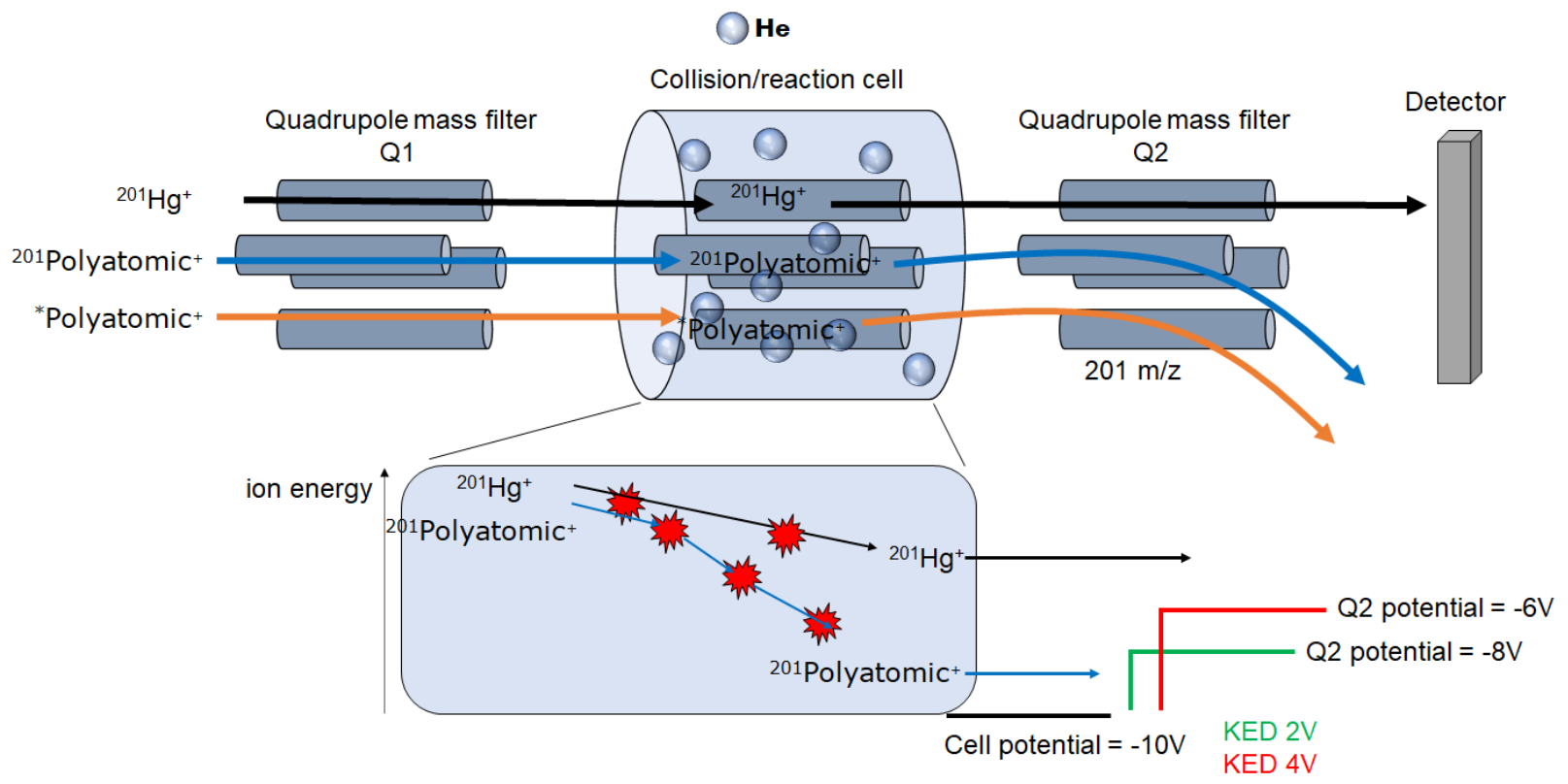

Figure 1. Polyatomic interference (or isobaric interference) can be attenuated via kinetic energy discrimination. Kinetic energy discrimination is defined as the use of a potential energy barrier between the collision/reaction cell and the mass analyzer to attenuate isobaric interference from polyatomic species. In a single-quadrupole mode, Quadrupole 1 (Q1) is set to let ions of all m/z pass through. The target element $\left({ }^{201} \mathrm{Hg}^{+}\right)$, polyatomic species with the same $\mathrm{m} / \mathrm{z}\left({ }^{201}\right.$ Polyatomic $\left.{ }^{+}\right)$, and other ions $\left({ }^{*}\right.$ Polyatomic $\left.{ }^{+}\right)$are introduced into the collision/reaction cell. In no-gas mode (not shown), all ions travel unhindered to quadrupole 2 (Q2) and ions with the target $\mathrm{m} / \mathrm{z}$ value (201 $\mathrm{m} / \mathrm{z}$ ) are selected by Q2. In helium mode, the collision/reaction cell is filled with helium and polyatomic species that can potentially cause 
isobaric interference undergo more collisions compared to ${ }^{201} \mathrm{Hg}^{+}$. The resulting kinetic energy discrepancy can be taken advantage of to filter out ${ }^{201}$ Polyatomic ${ }^{+}$by setting up a potential energy barrier, the magnitude of which can be manipulated by adjusting the potential difference between the collision/reaction cell and Q2.

When the collision/reaction cell is filled with non-reactive gas such as helium, the atomic ions (analyte ions) and the isobaric polyatomic ions (interfering ions) undergo multiple collisions with gas atoms. The former loses less kinetic energy than the latter during this process, resulting in energy difference between the two ion species of the same mass. By setting up a potential barrier of an appropriate magnitude, interfering polyatomic species can be filtered out while minimizing the loss of the target analyte, as shown in Figure 1. The efficiency of this suppression of isobaric interference, referred to as kinetic energy discrimination or KED, depends on a potential barrier that is neither too high nor too low. ${ }^{35}$ Students were encouraged to investigate the effect of this parameter by conducting the experiment at two different $\mathrm{KED}$ voltages, $2 \mathrm{~V}$ and $4 \mathrm{~V}$.

This experiment incorporates many key concepts of analytical chemistry research including method verification, matrix effect examination, parameter optimization, and quantification using external calibration curves. This paper focuses on the analysis of $\mathrm{Hg}$ in commercial fish products in a classroom setting. However, the general methodology can be applied to any sample that can be digested with $\mathrm{HNO}_{3}$ or $\mathrm{HCl}$ and with any element susceptible to polyatomic interference during ICP-MS analysis.

\section{MATERIALS \& METHODS}

Reagents

Hydrochloric acid 37\%, $\geq 99.999 \%$ trace metals basis (Sigma-Aldrich, Cat. no. 339253), nitric acid 70\%, purified by redistillation, $\geq 99.999 \%$ trace metals basis (Sigma-Aldrich, Cat. no. 225711), hydrogen peroxide 30\%, for trace analysis (Sigma-Aldrich, Cat. no. 95321), and water, ultra-trace elemental analysis grade (Fisher, Cat. no. W9-1) were used to generate matrices for digestion and analysis. Scandium stock solution $100 \mu \mathrm{g} / \mathrm{mL}, 7 \% \mathrm{HNO}_{3}$ (Inorganic Ventures, part no. CGSC10$125 \mathrm{ML}$ ) and Yttrium stock solution $100 \mu \mathrm{g} / \mathrm{mL}, 2 \% \mathrm{HNO}_{3}$ (Inorganic Ventures, part no. MSY-100PPM$125 \mathrm{ML}$ ) was diluted to $8 \mathrm{ng} / \mathrm{mL}$ and $4 \mathrm{ng} / \mathrm{mL}$, respectively, with either $2 \% \mathrm{HNO}_{3} / 0.34 \% \mathrm{H}_{2} \mathrm{O}_{2}$ or $2 \%$ $\mathrm{HNO}_{3} / 1 \% \mathrm{HCl} / 0.34 \% \mathrm{H}_{2} \mathrm{O}_{2}$ matrix to generate internal standard (ISTD) solutions (Sc $8 \mathrm{ng} / \mathrm{mL}, \mathrm{Y} 4$ 
$\mathrm{ng} / \mathrm{mL}$ ). Mercury standard $10 \mu \mathrm{g} / \mathrm{mL}, 5 \% \mathrm{HNO}_{3}$ (Agilent, part no. 5190-8575) was diluted with either $2 \% \mathrm{HNO}_{3} / 0.34 \% \mathrm{H}_{2} \mathrm{O}_{2}$ or $2 \% \mathrm{HNO}_{3} / 1 \% \mathrm{HCl} / 0.34 \% \mathrm{H}_{2} \mathrm{O}_{2}$ matrix to generate $10 \mathrm{ng} / \mathrm{mL}$ stock solution, which was used to make calibration solutions (see Calibration Curve Solutions Preparation for details). ICP-MS tuning solution $10 \mu \mathrm{g} / \mathrm{mL} \mathrm{Ce}, \mathrm{Co}, \mathrm{Li}, \mathrm{Mg}, \mathrm{Tl}, \mathrm{Y}$ (Agilent, part no. 5190-0465) was diluted 1,000-fold to $10 \mu \mathrm{g} / \mathrm{L}$ with $2 \% \mathrm{HNO}_{3}$ to conduct plasma warm-up runs and auto-tuning (see Instrument Parameters \& Auto Tuning section for details). SRM 1947 (Lake Michigan Fish Tissue, certification date 9/3/2020, expiration date $12 / 31 / 2026$ ) was purchased from NIST. ${ }^{25}$ Canned tuna (albacore tuna in water, Thailand) was purchased from a local supermarket. After the digestion, (see Microwave Digestion \& Sample Preparation section for details) the samples were stored in acidresistant Nalgene ${ }^{\mathrm{TM}}$ Narrow-Mouth Bottles Made of Teflon ${ }^{\mathrm{TM}}$ PFA (Fisher, Cat. no. DS1630-0001). Microwave Digestion \& Sample Preparation

Table 1. Microwave digestion sample parameters.

$\begin{array}{crcc}\text { Sample } & \text { Initial Mineralization In } & \begin{array}{c}\text { Sample } \\ \text { weight (g) }\end{array} & \begin{array}{c}\text { Final sample } \\ \text { volume }(\mathrm{mL})\end{array} \\ \text { Method Blank } & 5 \mathrm{~mL} \text { of } 70 \% \mathrm{HNO}_{3}, 2 \mathrm{~mL} \text { of } 30 \% \mathrm{H}_{2} \mathrm{O}_{2} & \mathrm{~N} / \mathrm{A} & 50 \\ \text { Method Blank } & 4 \mathrm{~mL} \text { of } 70 \% \mathrm{HNO}_{3}, 1 \mathrm{~mL} \text { of } 37 \% \mathrm{HCl}, 2 \mathrm{~mL} \text { of } 30 \% \mathrm{H}_{2} \mathrm{O}_{2} & \mathrm{~N} / \mathrm{A} & 50 \\ \text { Canned Tuna Meat } & 5 \mathrm{~mL} \text { of } 70 \% \mathrm{HNO}, 2 \mathrm{~mL} \text { of } 30 \% \mathrm{H}_{2} \mathrm{O}_{2} & 1.183 & 50 \\ \text { Canned Tuna Meat } & 4 \mathrm{~mL} \text { of } 70 \% \mathrm{HNO}_{3}, 1 \mathrm{~mL} \text { of } 37 \% \mathrm{HCl}, 2 \mathrm{~mL} \text { of } 30 \% \mathrm{H}_{2} \mathrm{O}_{2} & 1.169 & 50 \\ \text { SRM 1947 } & 5 \mathrm{~mL} \text { of } 70 \% \mathrm{HNO}_{3}, 2 \mathrm{~mL} \text { of } 30 \% \mathrm{H}_{2} \mathrm{O}_{2} & 1.251 & 50 \\ \text { SRM } 1947 & 4 \mathrm{~mL} \text { of } 70 \% \mathrm{HNO}_{3}, 1 \mathrm{~mL} \text { of } 37 \% \mathrm{HCl}, 2 \mathrm{~mL} \text { of } 30 \% \mathrm{H}_{2} \mathrm{O}_{2} & 1.346 & 50\end{array}$

All samples were digested via microwave digestion. Microwave digestion was performed at the ICPMS facility within the UC Center for Environmental Implications of Nanotechnology at UCLA. Samples (SRM, tuna) were measured into clean Teflon vessels for acid digestion. The digestion was carried out using either a mixture of $7 \% \mathrm{HNO}_{3}$ and $3 \% \mathrm{H}_{2} \mathrm{O}_{2}$ or $7 \% \mathrm{HNO}_{3}, 3.7 \% \mathrm{HCl}$, and $3 \% \mathrm{H}_{2} \mathrm{O}_{2}$ (see Table 1. for details) at $190^{\circ} \mathrm{C}$ for 20 minutes in a microwave digestion system (Titan MPS, PerkinElmer). Once the samples were cooled to room temperature, it was subsequently diluted to the final volume of $50 \mathrm{~mL}$ by adding filtered deionized water. Samples were then stored in $a-4^{\circ} \mathrm{C}$ freezer overnight and then analyzed the next morning (Day 1). After the Day 1 analysis, the samples were stored in a $4{ }^{\circ} \mathrm{C}$ refrigerator for 7 days and then re-analyzed (Day 8). 
Prior to ICP-MS analysis, $2 \mathrm{~mL}$ of each sample (method blank, tuna, SRM) was transferred to a rinsed (rinse protocol described below) $15 \mathrm{~mL}$ conical tube and subsequently diluted using $5 \mathrm{~mL}$ of ultra-trace elemental analysis grade water (see Reagents section for details). All samples were prepared in triplicate, such that a total of 9 vials (3x method blank, 3x tuna, 3x SRM) would be analyzed per run.

Rinse Protocol: The exterior, interior, and caps of $15 \mathrm{~mL}$ conical tubes were rinsed thrice with deionized water. Then, the interior of each tube was rinsed twice with either $2 \% \mathrm{HNO}_{3}$ or $2 \% \mathrm{HNO}_{3} / 1 \%$ $\mathrm{HCl}$, depending on the final matrix.

\section{Calibration Curve Solutions Preparation}

Calibration curve solutions were prepared by first generating a $10 \mathrm{ng} / \mathrm{mL}, 50 \mathrm{~mL}$ stock solution of mercury in an acid matrix of either $2 \% \mathrm{HNO}_{3} / 0.34 \% \mathrm{H}_{2} \mathrm{O}_{2}$ or $2 \% \mathrm{HNO}_{3} / 1 \% \mathrm{HCl} / 0.34 \% \mathrm{H}_{2} \mathrm{O}_{2}$. For the blank, a $15 \mathrm{~mL}$ conical tube was filled with $10 \mathrm{~mL}$ of ultra-trace metal grade water. For the $0 \mathrm{ng} / \mathrm{mL}$ solution, a $15 \mathrm{~mL}$ conical tube was filled with $10 \mathrm{~mL}$ of the acid matrix $\left(2 \% \mathrm{HNO}_{3} / 0.34 \% \mathrm{H}_{2} \mathrm{O}_{2}\right.$ or $2 \%$ $\mathrm{HNO}_{3} / 1 \% \mathrm{HCl} / 0.34 \% \mathrm{H}_{2} \mathrm{O}_{2}$ ) only. Serial dilution was used to produce calibration solutions with mercury concentrations of $0.5,1,2$, and $3 \mathrm{ng} / \mathrm{mL}$. A batch of fresh calibration solutions was prepared for each run.

\section{ICP-MS Instrument \& Batch Design}

This experiment used the Agilent 8800-QQQ ICP-MS instrument in the Molecular Instrumentation Center at UCLA. The instrument was operated using Agilent's MassHunter 4.1 software. Experiment batch design was reviewed with students prior to the start of the run (detailed information available in the Supplementary Information 1). Method blank, SRM, and tuna samples were analyzed in triplicates. Rinse steps were inserted between the samples to prevent cross contamination. All reported concentrations were average values from five technical replicates.

Instrument Parameters \& Auto Tuning

Table 2. Instrument parameters.

\begin{tabular}{|c|c|c|c|}
\hline RF Power & $1550 \mathrm{~W}$ & Nebulizer Pump & 0.10 revolutions per second \\
\hline RF Matching & $1.80 \mathrm{~V}$ & S/C Temp & $2{ }^{\circ} \mathrm{C}$ \\
\hline Sampling Depth & $8.0 \mathrm{~mm}$ & Gas Switch & Dilution Gas \\
\hline Carrier Gas & $1.00 \mathrm{~L} / \mathrm{min}$ & $\begin{array}{c}\text { Makeup/Dilution } \\
\text { Gas }\end{array}$ & $0.20 \mathrm{~L} / \mathrm{min}$ \\
\hline
\end{tabular}


Option Gas $\quad 0.0 \%$

170 Key plasma parameters that were maintained for all experiments are shown here. KED voltage was set at either $2 \mathrm{~V}$ or $4 \mathrm{~V}$ for no gas or helium mode for each matrix. After the plasma warm-up, auto tuning was performed before each run to calibrate the quadrupole and ion lens voltages to reach optimal signal intensity for target elements in the tune mix solution. ${ }^{33}$ The tune reports for each run are available in Supporting Information 3.

\section{HAZARDS}

Students should always wear protective goggles, gloves, and lab coats during the experiment. $70 \%$ $\mathrm{HNO}_{3}$ and $37 \% \mathrm{HCl}$ used for mercury extraction are extremely caustic and should be handled with care. The calibration solutions that contain $\mathrm{HNO}_{3}, \mathrm{HCl}$, and mercury should be generated with care in a well-ventilated fume hood and should not be kept for more than a few days. Finally, it is recommended that the autosampler chamber be ventilated during and after the experiment so that any vapor build-up containing mercury is minimized.

\section{RESULTS AND DISCUSSION}

All data was generated by student volunteers who took Chem 184 (analytical chemistry class for upper-division undergraduate students) at UCLA during the Winter 2021 quarter. 


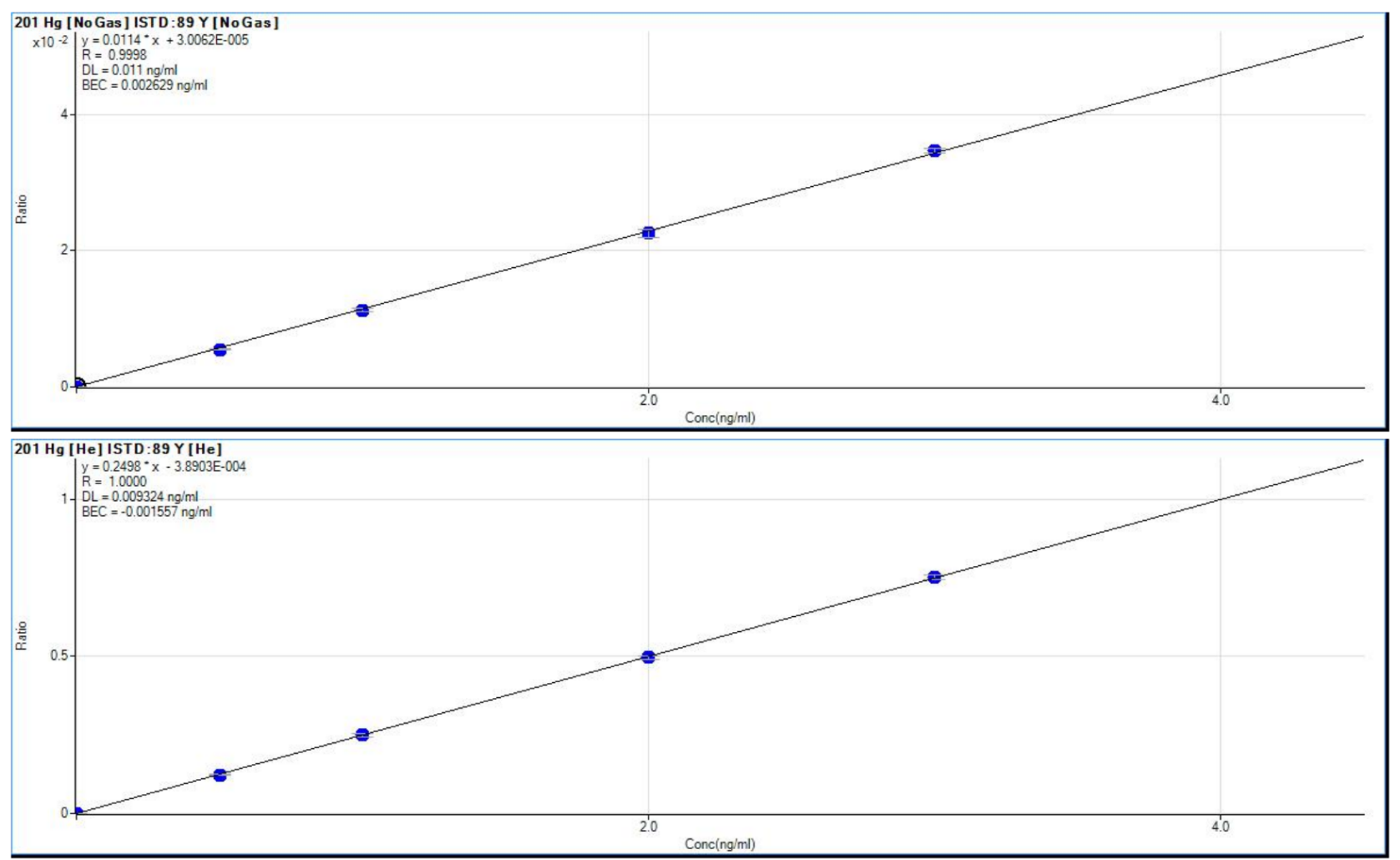

Figure 2. Student-generated calibration curves. Two representative calibration curves for $2 \% \mathrm{HNO}_{3} / 0.34 \% \mathrm{H}_{2} \mathrm{O}_{2}$, $2 \mathrm{~V} \mathrm{KED}$, no gas mode trial (top) and $2 \% \mathrm{HNO}_{3} / 1 \% \mathrm{HCl} / 0.34 \% \mathrm{H}_{2} \mathrm{O}_{2}, 4 \mathrm{~V} \mathrm{KED,} \mathrm{He} \mathrm{mode} \mathrm{trial} \mathrm{(bottom)} \mathrm{are} \mathrm{shown} \mathrm{here.}$

Calibration curves were excellent overall, possessing correlation coefficients between 0.9909 and 1.000 across 16 calibration curves. Two representative calibration curves are shown in Figure 2. Detection limits calculated by MassHunter software were all below $0.01 \mathrm{ng} / \mathrm{mL}$, two orders of magnitude below the target mercury concentration range of both tuna and SRM samples. All remaining calibration curves, as well as internal standard recovery curves, are provided in Supporting Information 2. 
A.

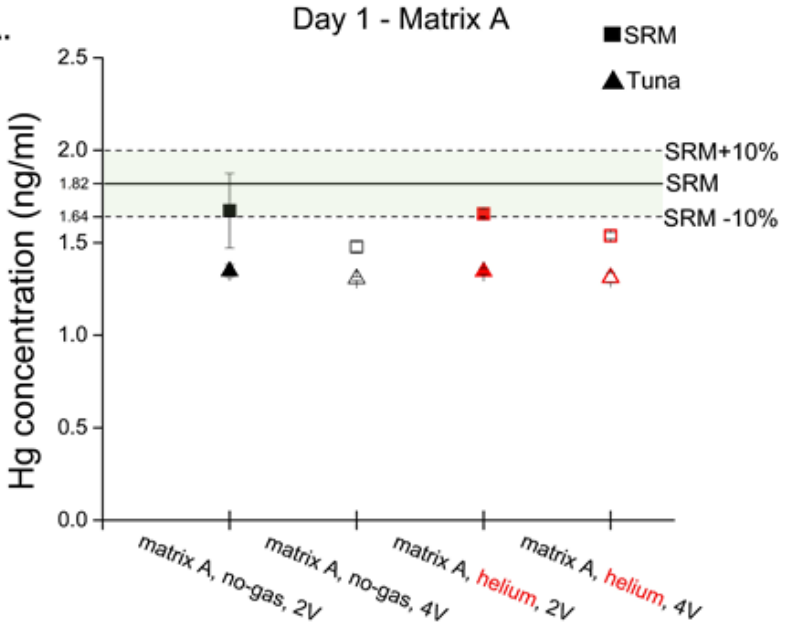

C.

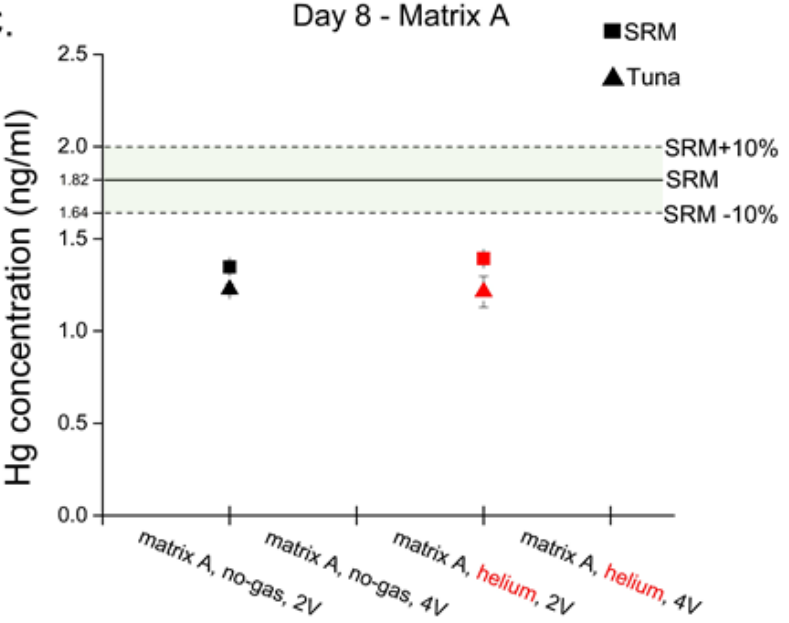

B.

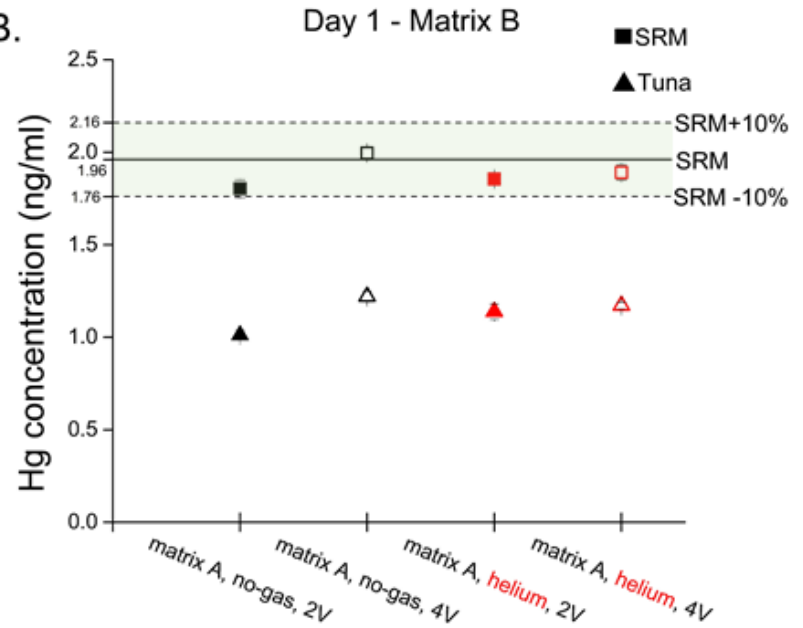

D.

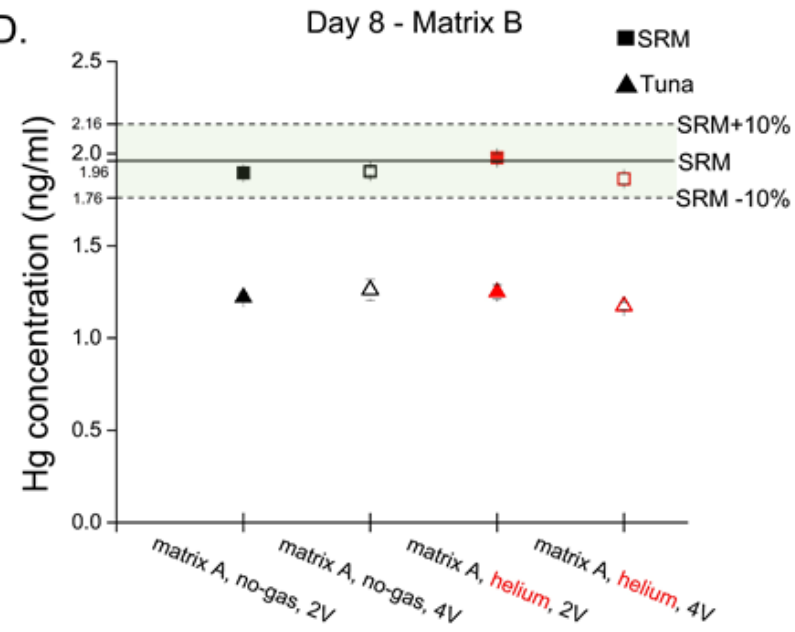

Figure 3. Day 1 and Day 8 student analysis results. A) Day 1 - Matrix A $\left(2 \% \mathrm{HNO}_{3} / 0.34 \% \mathrm{H}_{2} \mathrm{O}_{2}\right)$ results. Mean tuna and $\mathrm{SRM} \mathrm{Hg}$ concentrations were calculated from triplicate measurements. Expected SRM Hg concentration for Matrix A was $1.82 \mathrm{ng} / \mathrm{mL}$ and $\pm 10 \%$ margin of error is highlighted in green. B) Day 1 - Matrix $\mathrm{B}\left(2 \% \mathrm{HNO}_{3} / 1 \% \mathrm{HCl} / 0.34 \% \mathrm{H}_{2} \mathrm{O}_{2}\right)$ results. Expected SRM $\mathrm{Hg}$ concentration for Matrix B was $1.96 \mathrm{ng} / \mathrm{mL}$ and $\pm 10 \%$ margin of error is highlighted in green. C) Day 8 - Matrix A results. $4 \mathrm{~V}$ KED trial for Matrix A was excluded from analysis since the condition failed to meet the NIST standard of $\pm 10 \%$ margin of error on Day 1. D) Day 8 - Matrix B results.

Mean tuna and SRM mercury concentrations calculated from triplicate measurements (noted as [tuna] and [SRM] from here) on Day 1 and Day 8 are summarized in Figure 3. When samples were analyzed with Matrix A $\left(2 \% \mathrm{HNO}_{3} / 0.34 \% \mathrm{H}_{2} \mathrm{O}_{2}\right)$ on Day 1 , trials with $\mathrm{KED}=2 \mathrm{~V}$ met the NIST standard of $\pm 10 \%$ of expected $\mathrm{Hg}$ concentration while trials with $\mathrm{KED}=4 \mathrm{~V}$ failed. Similar trend was observed for both no gas mode and helium mode, in which heightened potential energy barrier lead to loss of the target ions. This result indicates that the kinetic energy of the target ions, determined by the instrument parameters set by the auto-tune run with Matrix A (see Supporting Information 3. for 
details), is not strong enough to overcome the $\mathrm{KED}$ voltage at $4 \mathrm{~V}$ and that there is minimal isobaric polyatomic interference.

Analysis of Day 8 samples followed identical methods; however, because the [SRM] in Matrix A failed to meet validation criteria at $\mathrm{KED}=4 \mathrm{~V}$ on Day 1 , this condition was excluded from Day 8 analysis. A decrease in [SRM] was observed for both no-gas mode (-19.4\%) and He-mode $(-15.9 \%)$ at $\mathrm{KED}=2 \mathrm{~V}$. These results agree with previous studies demonstrating mercury loss of up to $50 \%$ after 10 days, depending on sample container. ${ }^{28,29}$ This is especially relevant for undergraduate classes, since sample digestion availability may be limited due to cost or time constraints. Thus, unless the goal of the class is to investigate matrix effects on mercury stability over time, $\mathrm{HNO}_{3}$ or $\mathrm{HNO}_{3} / \mathrm{H}_{2} \mathrm{O}_{2}$ matrix composition should be avoided for long-term sample storage.

In contrast, [SRM] for Matrix $\mathrm{B}\left(2 \% \mathrm{HNO}_{3} / 1 \% \mathrm{HCl} / 0.34 \% \mathrm{H}_{2} \mathrm{O}_{2}\right)$ met the $\pm 10 \%$ margin of error for the expected value regardless of gas mode or KED voltage on Day 1. Curiously, higher potential energy barrier resulted in better accuracy for no gas mode, indicating that that interference attenuation by KED in no gas mode is possible. Similar result has been observed in a recent study but authors of the study states that there is no obvious explanation for this observation, and it may not be reproducible on all ICP-MS instruments, since it may be related to the plasma or interface system of the ICP-MS. ${ }^{36}$ Thus, detailed discussion of this result was deemed outside the scope of this class and was not pursued further. When KED voltage was at $2 \mathrm{~V}$, accuracy improved slightly when helium mode used compared to the no gas mode, indicating that KED with helium mode leads to sufficient kinetic energy discrepancy between interfering polyatomic species and the target ions so that $2 \mathrm{~V}$ potential barrier was effective. $4 \mathrm{~V}$ potential barrier was not too high to harm target ion detection significantly but resulted in slightly less accurate result for Day 8.

For Matrix B, Day 8 results did not differ significantly from Day 1 results and all SRM analysis fell within $\pm 5 \%$ margin of error from expected $\mathrm{Hg}$ concentration. This outcome agrees with previous studies that showed including $\mathrm{HCl}$ in the sample matrix enhances mercury stability over time. ${ }^{28,29}$ These results demonstrate the importance of choosing the correct matrix for the target element. Thus, for long-term storage of mercury samples for a class, $\mathrm{HNO}_{3} / \mathrm{HCl}$ or $\mathrm{HNO}_{3} / \mathrm{HCl} / \mathrm{H}_{2} \mathrm{O}_{2}$ matrix compositions are recommended. 
Based on these results, students concluded that Matrix B is the superior matrix for trace $\mathrm{Hg}$ analysis in regard to both the accuracy and the sample stability over time. Students reported that performance of He mode was slightly better than no gas mode but may be dependent on KED voltage. Students also deduced that the KED voltage had a more pronounced effect on samples analyzed with Matrix A. This indicates that $\mathrm{KED}=4 \mathrm{~V}$ is too high for Matrix A and results in significant loss of sensitivity. Students concluded that both 2V and 4V KED voltages worked well with Matrix B. These results indicate that sensitivity loss from higher KED voltages had less impact when the matrix included $\mathrm{HCl}$. From SRM analysis, students inferred that the tuna concentration from Matrix B, no gas, $\mathrm{KED}=4 \mathrm{~V}$ or Matrix $\mathrm{B}$, helium, $\mathrm{KED}=2 \mathrm{~V}$ trials are the most accurate results. From these two trials, students calculated the expected tuna's original mercury concentrations as $0.183 \mathrm{ppm}$ and $0.187 \mathrm{ppm}$, respectively. This was in close agreement with the FDA's value of $0.13 \mathrm{ppm} .7,34$

\section{CONCLUSION}

Students were asked to complete surveys before and after the experiment in order to assess learning objective progression. These survey results are provided in Supplementary Information 2. In short, prior to the experiment, students expressed neutral confidence in ICP-MS experimental design and execution. Concepts concerning polyatomic interference, gas modes, and method validation, and the rationale underlying the choice of acid matrix, were areas of particularly low understanding among the volunteers. After the experiment, students reported high understanding in these four areas. Students also reported a high degree of confidence that they could design and carry out their own analysis using ICP-MS. Many undergraduate institutions already have ICP-MS instrumentation for educational purposes. This protocol provides a straightforward way to explore major aspects of ICP-MS analysis while piquing students' interest by investigating a real-world problem.

\section{ASSOCIATED CONTENT}

Supporting Information

The Supporting Information is available on the ACS Publications website at DOI:

10.1021/acs.jchemed.XXXXXXX. [to be filled in by ACS.]

260 Supporting information (DOCX) - SI 1. Notes for instructors and students Supporting information (DOCX) - SI 2. Summary of raw data and surveys 
Supporting information (PDF) - SI 3. Summary of tune reports

\section{AUTHOR INFORMATION}

Corresponding Author

*E-mail: wonhyeukjung@ucla.edu

*E-mail: jloo@chem.ucla.edu

Notes

The authors declare no competing financial interest.

\section{ACKNOWLEDGMENTS}

The authors wish to thank Dr. Chonghyun Chang at the ICP-MS facility, UC Center for Environmental Implications of Nanotechnology, for his support for this project. The authors are also thankful for the contributions of the volunteer students from Chem 184 class, Ashton R. Davis, Viviann Q. Do, Ka Meng Lao, Sasha Gill-Ljunghammer, and Kenji G. Miura, whose hard work made this project possible. Finally, support from the US National Science Foundation (CHE-1808492 to JAL) and UCLA Instructional Improvement Programs Grant award \#20-12 is acknowledged.

\section{REFERENCES}

1. Bernhoft, R. A. Mercury Toxicity and Treatment: A Review of the Literature. J. Environ. Public Health. 460508 (2012).

2. Jernelöv, A., Landner, L. Larsson, T. Swedish Perspectives on Mercury Pollution. J. Water Pollut. Control. Fed. 47(4), 810-822 (1975).

3. Fujiki, M. \& Tajima, S. The Pollution of Minamata Bay by Mercury. Water Sci. Technol. 25(11), 133-140 (1992).

4. Jiang, G., Shi, J., Feng, X. Mercury Pollution in China. Environ. Sci. Technol. 40(12), 36723678 (2006).

5. Mason, R. P. \& Sheu, G.-R. Role of the ocean in the global mercury cycle. Global Biogeochem. Cycles. 16(4), 40-1 - 40-14 (2002).

6. World Health Organization. Mercury and health. https://www.who.int/news-room/factsheets/detail/mercury-and-health. Accession date: 6/10/2021 
7. Mercury Concentrations in Fish from the FDA Monitoring Program (1990-2010) | FDA. https://www.fda.gov/food/metals / mercury-concentrations-fish-fda-monitoring-program-19902010. Accession date: $6 / 10 / 2021$

8. Mercury Levels in Commercial Fish and Shellfish (1990-2012) | FDA. https://www.fda.gov/food/metals-and-your-food/mercury-levels-commercial-fish-andshellfish-1990-2012. Accession date: 6/10/2021

9. U.S. Food \& Drug Administration. Advice about Eating Fish. https://www.fda.gov/food/consumers/advice-about-eating-fish. Accession date: 6/10/2021

10. ATSDR - Public Health Statement: Mercury. https://www.atsdr.cdc.gov/PHS/PHS.asp?id=1128tid=24. Accession date: 6/10/2021

11. Guidance for Industry: Action Levels for Poisonous or Deleterious Substances in Human Food and Animal Feed | FDA. https://www.fda.gov/regulatory-information/search-fda-guidancedocuments / guidance-industry-action-levels-poisonous-or-deleterious-substances-human-foodand-animal-feed. Accession date: 6/10/2021

12. U.S. Food \& Drug Administration. Elemental Analysis Manual for Food and Related Products. Version 1.2 (2020). https://www.fda.gov/media/87509/download. Accession date: 6/10/2021 13. Pröfrock, D., Leonhard, P., Wilbur, S. \& Prange, A. Sensitive, simultaneous determination of P, $\mathrm{S}, \mathrm{Cl}, \mathrm{Br}$ and I containing pesticides in environmental samples by GC hyphenated with collision-cell ICP-MS. J. Anal. At. Spectrom. 19, 623-631 (2004).

14. Allibone, J., Fatemian, E. \& Walker, P. J. Determination of mercury in potable water by ICP-MS using gold as a stabilising agent. J. Anal. At. Spectrom. 14, 235-239 (1999).

15. Nardi, E. P. et al. The use of inductively coupled plasma mass spectrometry (ICP-MS) for the determination of toxic and essential elements in different types of food samples. Food Chem. $112,727-732$ (2009).

16. Maione, C. et al. Comparative study of data mining techniques for the authentication of organic grape juice based on ICP-MS analysis. Expert Syst. Appl. 49, 60-73 (2016). America. J. Chem. Educ. 77(5), 598-607 (2000). 
18. Sanders, J. K. Inductively Coupled Plasma-Mass Spectrometry: Practices and Techniques (Taylor, Howard E.). J. Chem. Educ. 78, 1465 (2001).

19. Donnell, A. M., Nahan, K., Holloway, D. \& Vonderheide, A. P. Determination of Arsenic in Sinus Wash and Tap Water by Inductively Coupled Plasma-Mass Spectrometry. J. Chem. Educ. 93, 738-741 (2016).

20. He, P., Colón, L. A. \& Aga, D. S. Determination of Total Arsenic and Speciation in Apple Juice by Liquid Chromatography-Inductively Coupled Plasma Mass Spectrometry: An Experiment for the Analytical Chemistry Laboratory. J. Chem. Educ. 93, 1939-1944 (2016).

21. Schwarz, G. et al. Protein Quantification by Elemental Mass Spectrometry: An Experiment for Graduate Students. J. Chem. Educ. 91, 2167-2170 (2014).

22. Managh, A.J., Reid, P., \& Knox, M.A. Development and Use of "ICP-MS TuneSim": A Software App that Allows Students to Simulate Tuning an Inductively Coupled Plasma Mass Spectrometer. J. Chem. Ed. 95(11), 2059-2063 (2018).

23. Kristian, K.E. et al. A simplified digestion protocol for the analysis of $\mathrm{Hg}$ in fish by cold vapor atomic absorption spectroscopy. J. Chem. Ed. 92(4), 698-702 (2015).

24. Bulska, E. et al. On the use of certified reference materials for assuring the quality of results for the determination of mercury in environmental samples. Environ. Sci. Pollut. Res. Int. 24(9), 7889-7897 (2017).

25. National Institute of Standards and Technology. Standard Reference Materials, SRM Online Request System. https://www-s.nist.gov/srmors/view_detail.cfm?srm=1947 Accession date: $05 / 25 / 2021$

26. Agilent Technologies, Inc., 2011, January 17, 2011, 5990-7173EN. Successful Low Level Mercury Analysis.

27. Wang, X.-M., Wang, K., Zeng, X.-C., Hsu, D. \& Song, J.-E. Accurate Analysis of Trace Mercury in Cosmetics using the Agilent 8900 ICP-QQQ.

28. Krivan, V. \& Haas, H. F. Prevention of loss of mercury(II) during storage of dilute solutions in various containers. Fresenius' Zeitschrift für Anal. Chemie 332, 1-6 (1988). 
29. Louie, H., Wong, C., Huang, Y. J. \& Fredrickson, S. A study of techniques for the preservation of mercury and other trace elements in water for analysis by inductively coupled plasma mass spectrometry (ICP-MS). doi:10.1039/c2ay05182f.

30. Zhu, Y., Ahmady, B., Numata, M. \& Chiba, K. Solid phase extraction using a sulfoxide adsorbent for preconcentration and separation of $\mathrm{Hg}$ (II) in natural water followed by ICP-MS measurements. Anal. Sci. 28, 417-422 (2012).

31. Handbook of ICP-QQQ Applications using the Agilent 8800 and $89004^{\text {th }}$ edition https://www.agilent.com/cs/library/applications/appcompendium_icp-qqq-5991-2802en-usagilent.pdf. Accession date: 6/10/2021

32. Iglesias, M., Gilon, N., Poussel, E., Mermet, J. Evaluation of an ICP-collision/reaction cell-MS system for the sensitive determination of spectrally interfered and non-interfered elements using the same gas conditions. J. Anal. At. Spectrom. 17, 1240-1247 (2002).

33. Agilent Technologies, Inc., 2015, November 4, 2015, 5991-6409EN. Routine soil analysis using an Agilent 8800 ICP-QQQ.

34. U.S. Environmental Protection Agency. EPA-FDA Fish Advice: Technical Information. https://www.epa.gov/fish-tech/epa-fda-fish-advice-technical-information. Accession date: $6 / 1 / 21$.

35. Yamada, N. Kinetic energy discrimination in collision/reaction cell ICP-MS: Theoretical review of principles and limitations. Spectrochim. Acta Part B At. Spectrosc. 110, 31-44 (2015).

36. Sugiyama, N. Attenuation of doubly charged ion interferences on arsenic and selenium by ICPMS under low kinetic energy collision cell conditions with hydrogen cell gas. J. Anal. At. Spectrom. 36, 294-302 (2021). 